\title{
REVIEW I Singing the Body Electric: The Human Voice and Sound Technology
}

\author{
Miriama Young
}

Farnham: Ashgate, 2015

ISBN: 9780754669869 (HB)

\section{Katerina Tzedaki \\ Technological Educational Institute of Crete tzed@staff.teicrete.gr}

Miriama Young's monograph on human voice and sound technology successfully introduces and guides the reader, and listener, through a vast range of material on the topic, which includes music, aesthetics, philosophy, history, musical practice and techniques, literature, sound, film and theatre by writers, such as Jean Paul Sartre (1938), Sammuel Becket (1973), Theodor Adorno (1990), Pierre Schaeffer (1966), Simon Frith (1990), Marshall McLuhan (1964), Carolyn Abbate (1991), Rene Girard (1965), Michel Chion (1999), Mladen Dolar (2006), Jean Baudrillard (1994), Jonathan Sterne (2003), and Trevor Wishart (1996). The author examines the transformations of the voice through sound technology devices and their subsequent implications in music and sound art, in perception and everyday life from a historical and analytical perspective.

It is not just the information and the music examples discussed, the literature cited, or the links made with philosophy, history, and other domains that validate Young's attempt to talk about and around the voice, its transformations and extensions through sound technologies, as well as its displacement, embodiment, dis- and re- embodiment. It is mostly the discussion on them throughout the entire text that enables the reader to further their understanding, and become also aware of the connections with fields of human wandering, contemplation and art practices that differ from music.

While it seems that it is almost impossible to define what the voice is as Mladen Dolar (2006), Michel Chion (1999) and Young support, paradoxically the sound of 
the human voice is inseparable from the person who owns it, acting like an identity stamp - regardless of the medium through which it is heard. Speech, song, inner voice, language or paralanguage, expression of feelings and meanings, all aspects of human civilization are inherently bound up with the voice. It is thus not surprising that the focus of our attention to vocal sound is almost involuntary. In this technological era starting from the previous century, the means and mediums through which the voice has been extended, and multiplied, and has evolved, result in various new applications in the arts.

The book contains five chapters, each of which examines different facets of the theme, five interviews with pioneer electroacoustic music composers, and finally a sixth voice (her voice) by way of interludes. Through this sixth voice she partly documents her compositions that are included in the album Speak Volumes, a work connected with the theme of the monograph. The structure of the book is intriguing as it embodies - interleaved with the main narrative - interviews, etymological references, and interludes, while most of the titles of the chapters and sub-chapters use a highly poetic language. The sequential combination of the academic with a more intimate or personal language of the interviews and interludes is striking, even remarkable, as the thread of thought is kept intact until the end of the text.

Young is starting from the condition that the voice could be interpreted as a piece of highly sophisticated technology, and intellectually dissolves the separation of human and machine, considering the mediated voice as technology and all subsequent transformations as extensions of the voice in a "continuum - in which the 'voice' is always technology" (6, italics in original). In line with Descartes' early conceptions of the human body as a machine (10), she examines how the connection between voice, body, and technology has been applied in the music of the western culture for the last 150 years. Although this approach is consistent and validated in academic terms, one cannot put aside the idea that the voice not only indicates the operations of the human body in the production of sound, but also reflects the state of specific human beings, of their feelings, culture, community, soul, and mind. The voice operates at the same time as a mirror of the being and as the medium through which the words, the cry, the laugh, the pain, the song, and much more are transmitted.

We could speculate that the voice is the very first and ultimate musical instrument, thus the extended voice through technological means whether as technology or not is at the very core of the human personal and cultural creative practices. So it is not surprising that Young includes in the discussion all these different facets of western culture.

Her research on the topic here results in a carefully combined reading of the signs, sounds, and words of our times, ranging from popular to avant-garde and academic approaches, to musical composition and practice. She not only analyses the vocal element in its relation to the body and the technology as applied in the music of Damon Albarn, Dager Mouse, Matmos, Alvin Lucier, Bjork, Pierre 
Schaeffer, Pierre Henry, Yiannis Kyriakides, Radiohead, John Chowning, Paul Lansky, Imogen Heap, Pamela Z, Kraftwerk, Ser, Ernst Tosch, Paul Hindemith, Janet Jackson, Q-Tip, Luciano Berio, Christian Marclay, Moby, Gerstman, Kelly and Mathews, and the voice of HAL-9000, but she also offers a list of 525 more works to enable further study of the theme. Moreover, the decision to interview and include in this book the experiences and different voices of Trevor Wishart, Katharine Norman, Paul Lansky, Eduardo Reck Miranda, and Bora Yoon, gives the reader access to valuable historical source material, while adding more voices to the comparisons here of thought, chorus and effect.

How to read, and listen to, this publication is a matter that inevitably could include many different approaches and types of listening, but it is definitely a monograph that invites the reader to come back to again and again, to discover and re-discover more voices, ideas, narratives, discussions, music, sounds, and valuable source materials. It is an amazing work in which you do not have to agree with all the different voices in order to participate.

\section{References}

Abbate, C. 1991. Unsung Voices: Opera and Musical Narrative in the Nineteenth Century. Princeton, NJ: Princeton University Press.

Adorno, T. -

1990a. The Curves of the Needle. October 55: 48-55.

1990b. The Form of the Phonograph Record. October 55: 56 -61.

Baudrillard, J. 1994. Simulacra and Simulation: The Body, in Theory, trans. Sheila Faria Glaser. Ann Arbor, MI: University of Michigan Press.

Beckett, S. 1973. Not I. London: Faber.

Chion, M. 1999. The Voice in Cinema, trans. Claudia Gorbman. New York: Columbia University Press.

Dolar, M. 2006. A Voice and Nothing More. Cambridge, MA: MIT Press.

Frith, S. 1996. Performing Rites: On the Value of Popular Music. Cambridge, MA: Harvard University Press.

Girard, R. 1965. Deceit, Desire and the Novel: Self and Other in Literary Structure, trans. Bernard Grasset. Baltimore, MD: The Johns Hopkins University Press.

McLuhan, M. 1964. Understanding Media: The Extensions of Man. New York: New American Library.

Sartre, J.P. 1964. Nausea, trans. Lloyd Alexander. New York: New Directions.

Schaeffer, P. 1966. Traité Des Objets Musicaux, Essai Interdisciplines. Paris: Éditions du Seuil.

Sterne, J. 2003. The Audible Past: Cultural Origins of Sound Reproduction. Durham, NC, and London: Duke University Press.

Wishart, T. 1996. On Sonic Art (Second Edition, revised by Simon Emmerson). Amsterdam: Harwood Academic Publishers. 